\title{
Effects of ENSO on Autumn Rainfall in Central Vietnam
}

\author{
Thang Van Vu, ${ }^{1}$ Hieu Trong Nguyen, ${ }^{2}$ Thang Van Nguyen, ${ }^{1}$ Hiep Van Nguyen, \\ Huong Thi Thanh Pham, ${ }^{1}$ and Lan Thi Nguyen ${ }^{1}$ \\ ${ }^{1}$ Vietnam Institute of Meteorology Hydrology and Climate Change (IMHEN), 23/62 Nguyen Chi Thanh, Dong Da, Hanoi, Vietnam \\ ${ }^{2}$ Center for Meteorology, Hydrology and Environment Science and Technology, 291/42/48 Lac Long Quan, Hanoi, Vietnam
}

Correspondence should be addressed to Hiep Van Nguyen; hiepwork@gmail.com

Received 18 April 2014; Revised 10 July 2014; Accepted 16 September 2014

Academic Editor: Sahra Kacimi

Copyright (c) 2015 Thang Van Vu et al. This is an open access article distributed under the Creative Commons Attribution License, which permits unrestricted use, distribution, and reproduction in any medium, provided the original work is properly cited.

28 years (1980-2007) of station and gridded reanalysis data were used to investigate the effects of El Niño/Southern Oscillation (ENSO) on autumn rainfall in the Extended Central Vietnam (ECV) region. Results show that, under El Niño conditions, autumn rainfall in Central Vietnam is reduced by about 10 to 30\%. This reduction seems to be caused by a weakening of the North East monsoon circulation, which appears to be linked to an anomalous anticyclonic vortex and a positive sea level pressure anomaly over the East Sea. In addition, the disappearance of a secondary moisture source over the southern region of the East Sea also favors the reduction in rainfall over this region. Conversely, during La Niña, the total autumn rainfall in the ECV region increases by about 9 to $19 \%$. The strengthening of the North East monsoon, with a cyclonic wind anomaly over the East Sea, helps to increase the moisture supply to the area by about 10 to $20 \%$, resulting in enhanced rainfall in the ECV. It is also found that the La Niña conditions do not only cause an increase in rainfall, but also change the temporal distribution of the monthly rainfall over the region, with more rainfall in the latter months of the year.

\section{Introduction}

Rainfall regimes in Vietnam are controlled by the monsoon system and tropical disturbances in the Intertropical Convergence Zone (ITCZ). While northern and southern Vietnam have maximum rainfall in the summer (June-July-August, JJA), Central Vietnam (CV) has its maximum monthly rainfall in autumn (September-October-November, SON). At some stations in $\mathrm{CV}$, the annual rainfall can reach between $3600 \mathrm{~mm}$ (Hue station) and $4000 \mathrm{~mm}$ (Ba To station) [1].

Rainfall distributions and rainy seasons in CV are significantly controlled by cold surges and tropical cyclones $[2,3]$. Chen et al. [2] studied the weather patterns associated with heavy rain events in the $\mathrm{CV}$ region and suggested that twothirds of the heavy rainfall events are caused by tropical cyclones. The remaining events are mostly related to the interaction between cold surges and tropical cyclones.

The El Niño/Southern Oscillation (ENSO) has noticeable effects on the variability of annual rainfall $[2,4-7]$. Over CV, there is a significant increase in the annual rainfall in $\mathrm{La}$ Niña years and a significant reduction in annual rainfall in
El Niño years $[2,5,6,8-10]$. Nguyen $[9,10]$ reported that, during El Niño years, the frequency of extreme daily rainfall in CV decreases, while during La Niña years, the frequency increases. Using rainfall data at Hue station for the period 1906-2006, Nguyen [11] stated that there is a decrease in the annual rainfall of more than $10 \%$ during most of the $\mathrm{El}$ Niño years. In contrast, the station experiences an increase in rainfall of about $13 \%$ or more during most La Niña years. Chen et al. [2] showed that maximum rainfall in CV in late autumn increases about $174 \%$ under La Niña conditions and decreases about $-52 \%$ under El Niño conditions. They also suggested that the late autumn rainfall maximum over the CV region is controlled by changes in the tropical cyclonic shear flow over the southeast Asia Pacific area in response to changes in sea surface temperature (SST) anomalies in the Niño-3.4 region [2].

In this paper, the role of local circulations and moisture transport over the East Sea on autumn (SON) rainfall over the Extended Central Vietnam (ECV) region, defined as the part of Vietnam ranging from $120^{\circ} \mathrm{N}$ to $19^{\circ} \mathrm{N}$ (Figure 1), during ENSO is investigated further using high resolution 


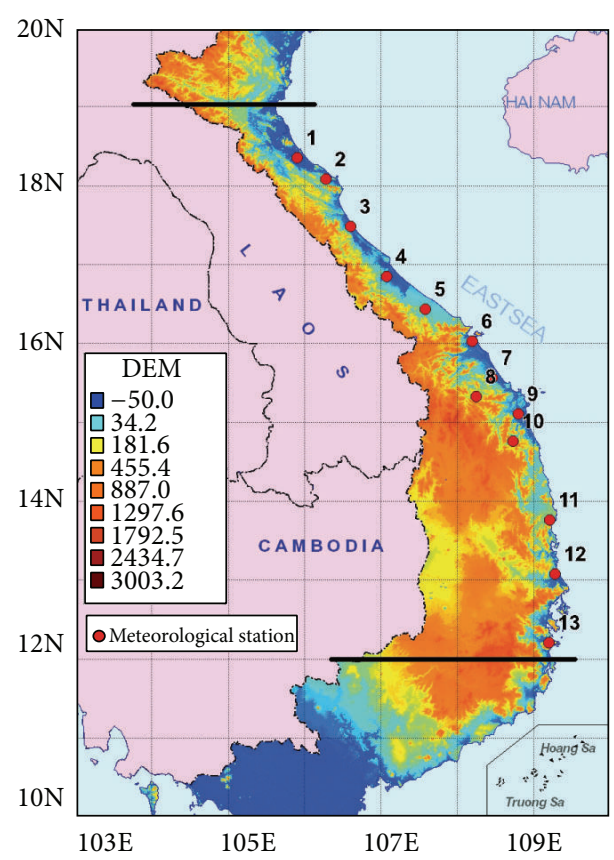

FIGURE 1: Terrain height ( $\mathrm{m}$, shaded) and locations of the 13 coastal stations (red dots). The two black bars indicate the northern and southern boundaries of the ECV region.

(0.5 degrees) Climate Forecast System Reanalysis (CFSR) data and station observations. In addition to the effects of ENSO on total rainfall, the effects of ENSO on shifting the rainfall season in the ECV region are also investigated. The objectives of this work are to investigate (i) the changes in local circulation over the East Sea and their effects on autumn rainfall over the ECV region; (ii) the role of moisture sources and their changes during ENSO on rainfall variability; and (iii) the effects of ENSO on the temporal distribution of monthly rainfall over the ECV under different ENSO conditions. The data sources and methods are presented in Section 2. Results are shown in Section 3. A summary and discussion are given in Section 4.

\section{Data and Method}

Monthly rainfall at stations, gridded rainfall data, and reanalysis data from 1980 to 2007 are used to investigate the effect of ENSO on autumn rainfall over the ECV region. Of the total of 27 stations over the ECV region, the 13 coastal stations (Table 1, Figure 1) are studied more comprehensively in the statistics and analyses, because autumn rainfall in the ECV region is mainly caused by moist air flows from the East Sea interacting with terrain and landmass. The station data are from the Vietnam Hydrometeorological Data Central (HMDC), Ministry of Natural Resources and Environment (MONRE). All station data have been quality controlled by the HMDC.

The gridded data include the Asian Precipitation Highly Resolved Observational Data Integration Towards Evaluation (APHRODITE) rainfall data (http://www.chikyu.ac.jp/) with
TABLE 1: Names and coordinates of the 13 coastal stations. The first column is station ID. The second column is station name. The third column is longitude. The fourth column is latitude.

\begin{tabular}{lccc}
\hline Number & Station name & Longitude $\left({ }^{\circ} \mathrm{E}\right)$ & Latitude $\left({ }^{\circ} \mathrm{N}\right)$ \\
\hline 1 & Ha Tinh & 105.9 & 18.35 \\
2 & Ky Anh & 106.28 & 18.08 \\
3 & Dong Hoi & 106.6 & 17.48 \\
4 & Dong Ha & 107.08 & 16.85 \\
5 & Hue & 107.58 & 16.43 \\
6 & Da Nang & 108.2 & 16.03 \\
7 & Tam Ky & 108.46 & 15.56 \\
8 & Tra My & 108.25 & 15.33 \\
9 & Quang Ngai & 108.8 & 15.11 \\
10 & Ba To & 108.73 & 14.76 \\
11 & Quy Nhon & 109.21 & 13.76 \\
12 & Tuy Hoa & 109.28 & 13.08 \\
13 & Nha Trang & 109.2 & 12.21 \\
\hline
\end{tabular}

a resolution of $0.25^{\circ} \times 0.25^{\circ}$, sea-level pressure (SLP) and zonal and meridional winds at $10 \mathrm{~m}$ and $850 \mathrm{hPa}$ levels from CFSR data from the National Centers for Environmental Prediction (NCEP) with a resolution of $0.5^{\circ} \times 0.5^{\circ}$. The total moisture transport vectors used to investigate the moisture sources affecting autumn rainfall over ECV are computed from winds and specific humidity at 1000, 925, 850,700, 600, 500, 400, and $300 \mathrm{hPa}$ levels obtained from the NCEP reanalysis data at a resolution of $2.5^{\circ} \times 2.5^{\circ}$. The method used to compute moisture transport vectors is from Sminov and Moor [12].

El Niño and La Niña conditions are determined using NOAA operational definitions based on the Oceanic Niño Index (ONI). The ONI is the three-month running mean of the SST anomaly (SSTA) from the climatological SST over the Niño 3.4 region $\left(5^{\circ} \mathrm{N}-5^{\circ} \mathrm{S}, 120^{\circ} \mathrm{W}-170^{\circ} \mathrm{W}\right)$. An El Niño occurs when there are at least five consecutive months with a positive ONI greater than or equal to $0.5^{\circ} \mathrm{C}$ and a La Niña occurs when there are at least five consecutive months with a negative ONI less than or equal to $-0.5^{\circ} \mathrm{C}$ [13]. In this work, only the years in which ENSO occurs in autumn are considered. Based on the above criteria, during the period from 1980 to 2007 there are nine El Niño autumns and ten La Niña autumns (Table 2).

\section{Results}

3.1. Characteristics of Autumn Rainfall and Circulation Patterns. The long-term (1980-2007) mean of autumn (SON) rainfall in ECV is shown in Figure 2. It can be seen that the mean ranges from about 800 to $2400 \mathrm{~mm}$. The four local rainfall maxima are at Ky Anh $(1740 \mathrm{~mm})$, Hue $(1887 \mathrm{~mm})$, Tra My $(2429 \mathrm{~mm})$, and Ba To $(2094 \mathrm{~mm})$ (Figure 2). The local maxima are located on the windward sides of the local terrain maxima (Figure 1). From this it can be inferred that terrain plays an important role in rainfall distribution over the ECV region. 
TABle 2: The autumn El Niño and La Niña years during the 19802007 period.

\begin{tabular}{lc}
\hline El Niño years & La Niña years \\
\hline 1982 & 1983 \\
1986 & 1984 \\
1987 & 1985 \\
1991 & 1988 \\
1994 & 1995 \\
1997 & 1998 \\
2002 & 1999 \\
2004 & 2000 \\
2006 & 2005 \\
& 2007 \\
\hline
\end{tabular}

Figure 3 shows the long-term mean of September, October, and November rainfall, computed from station rainfall data for the period 1980-2007. In September, the northern regions of ECV, from Nghe An to Da Nang, have rainfall of 350 to $400 \mathrm{~mm}$. There is another local maximum $(500 \mathrm{~mm})$ of rainfall at Ky Anh station (18.08 N, 106.26 E), whereas the coastal regions from Quang Ngai to Khanh Hoa have total rainfall of less than $300 \mathrm{~mm}$ (Figure 3(a)).

In October, rainfall increases significantly in the ECV region compared to that in September, with most of the monthly rainfall values ranging from 300 to $700 \mathrm{~mm}$ (Figure 3(b)). There are three local rainfall maxima located at Hue (832 mm), Tra My (1005 mm), and Ba To $(834 \mathrm{~mm})$. Two local rainfall minima, with rainfall of less than $300 \mathrm{~mm}$, occur at Khanh Hoa and Nghe An (Figure 3(b)). In November, the rainfall regime is similar to that in October. However, the rainfall amounts in November are less than those in October except for the rainfall maximum in the central region near Tra My station (Figure 3(c)).

The rainy season in the ECV region is regulated by the North East monsoon, tropical cyclones, tropical disturbances in the ITCZ, and cold surges, or a combination of these factors $[2,3]$ in the presence of high terrain in the Truong Son Mountain range to the west of ECV (Figure 1). The longterm mean of low-level wind vectors (Figure 4) shows that during the autumn months there are regions with strong $10 \mathrm{~m}$ northeasterly (Figure 4(a)) and easterly winds at the $850 \mathrm{hPa}$ level (Figure 4(b)) over the northeast portion of the East Sea. The wind vectors are almost perpendicular to the northeast-southwest direction of the Truong Son Mountain range (Figure 1). As discussed, the locations of the local rainfall maxima are almost consistent with the local maxima in the terrain heights. The interaction between the North East monsoon and the terrain may be one of the important factors controlling the autumn rainfall regime in the ECV region.

In addition to the instability caused by orographic forcing and blocking, moisture is also required for the formation of the observed rainfall over the ECV. The distribution of the total moisture transport vector in Figure 5 shows that, during the autumn months, abundant moisture is channeled into the East Sea from the Western Pacific. Therefore, the rainfall distribution over the ECV region is strongly influenced by

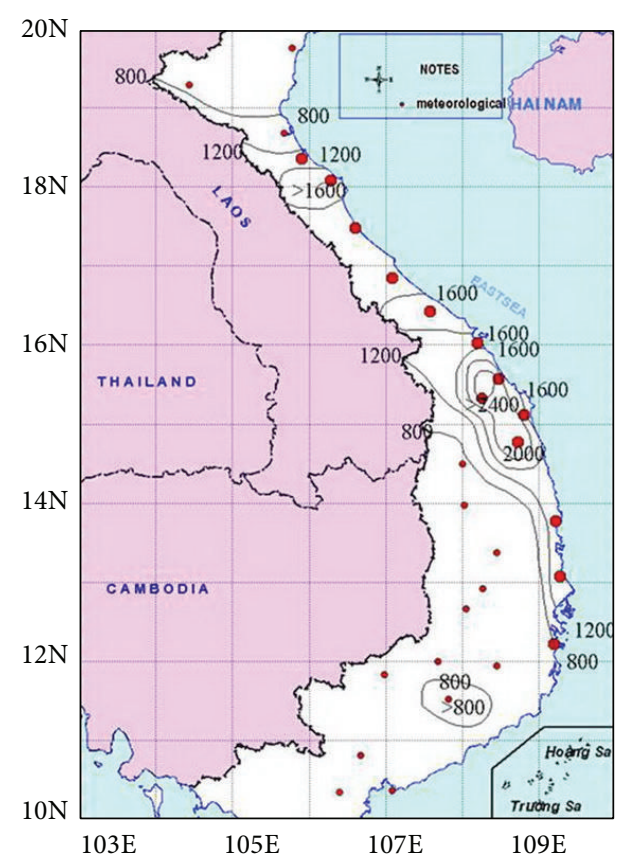

FIGURE 2: Long-term (1980-2007) means of autumn rainfall (mm).

TABLe 3: The rainfall anomalies during El Niño conditions at 13 coastal stations. The first column is station name. The second column is the rainfall anomaly (\%) for autumn. Columns 3, 4, and 5 indicate the rainfall anomaly (\%) for September, October, and November, respectively.

\begin{tabular}{lcccc}
\hline Stations & Autumn & Sep. & Oct. & Nov. \\
\hline Ha Tinh & -7.3 & -22.2 & -13.3 & 32.5 \\
Ky Anh & -11.0 & 5.6 & -34.0 & 12.7 \\
Dong Hoi & -8.2 & -9.8 & -15.7 & 9.3 \\
Dong Ha & -3.9 & -5.2 & -15.4 & 16.0 \\
Hue & -17.9 & -7.1 & -27.0 & -12.9 \\
Da Nang & -20.8 & -4.7 & -26.0 & -23.6 \\
Tam Ky & -26.4 & 13.8 & -32.9 & -38.2 \\
Tra My & -25.7 & 19.8 & -37.7 & -30.8 \\
Quang Ngai & -23.0 & 24.9 & -33.8 & -33.6 \\
Ba To & -23.4 & 30.4 & -45.7 & -21.4 \\
Quy Nhon & -16.5 & 15.7 & -30.0 & -16.1 \\
Tuy Hoa & -23.2 & 14.0 & -44.0 & -15.7 \\
Nha Trang & -30.3 & 7.1 & -41.9 & -37.2 \\
\hline
\end{tabular}

the activity of the North East monsoon. The variability in strength and direction of the monsoon flows and moisture availability during the ENSO cycle may affect the rainfall distribution and amount over the ECV region. This will be further investigated in the next section of this paper.

\subsection{Effects of ENSO on Autumn Rainfall in the ECV Region}

3.2.1. Effects of El Niño. To investigate the effect of El Niño on rainfall over the ECV region, rainfall anomalies for the autumn months in the El Niño years (Table 2) at 13 coastal stations are computed from 28 years (1980 to 2007) of station data (Table 3). Table 3 shows that all 13 coastal stations 


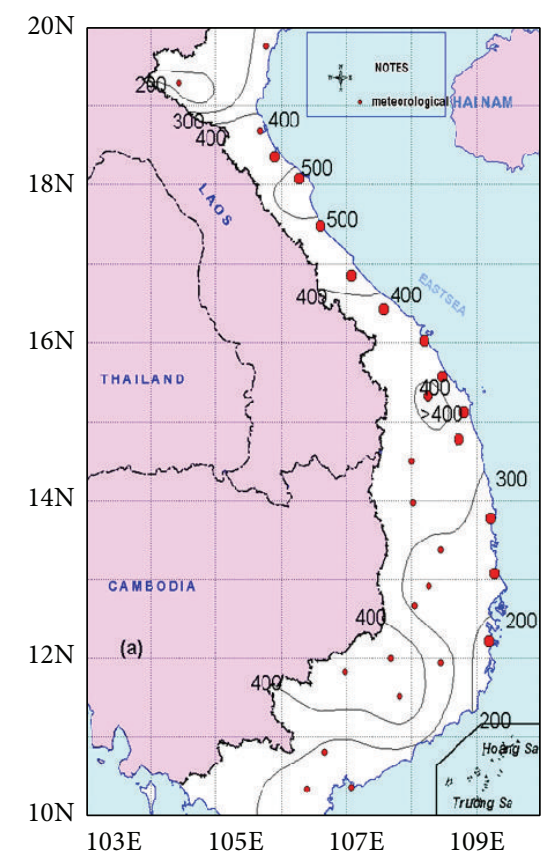

(a)

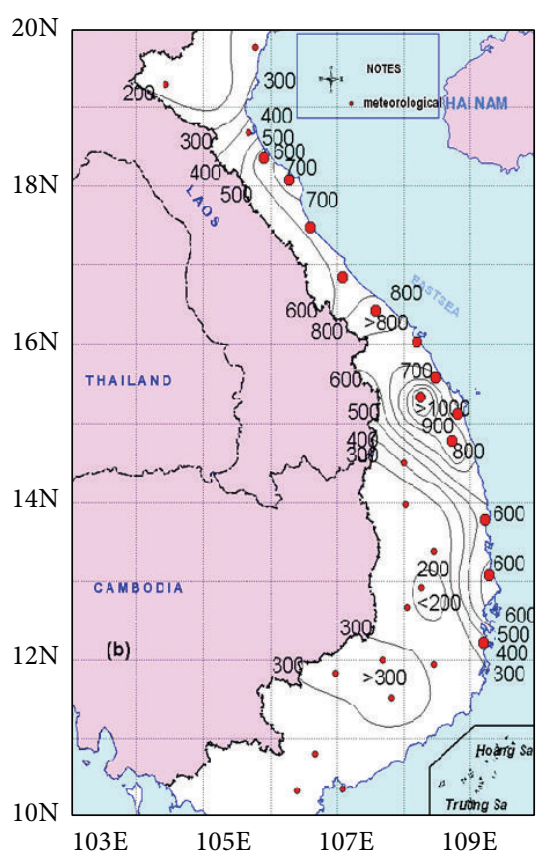

(b)

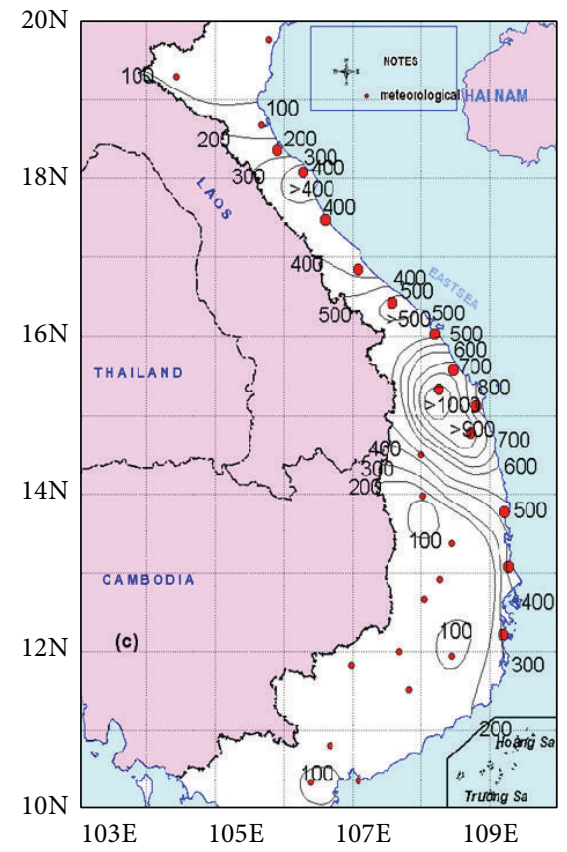

(c)

FIGURE 3: Long-term (1980-2007) means of monthly rainfall (mm) in ECV for (a) September, (b) October, and (c) November.

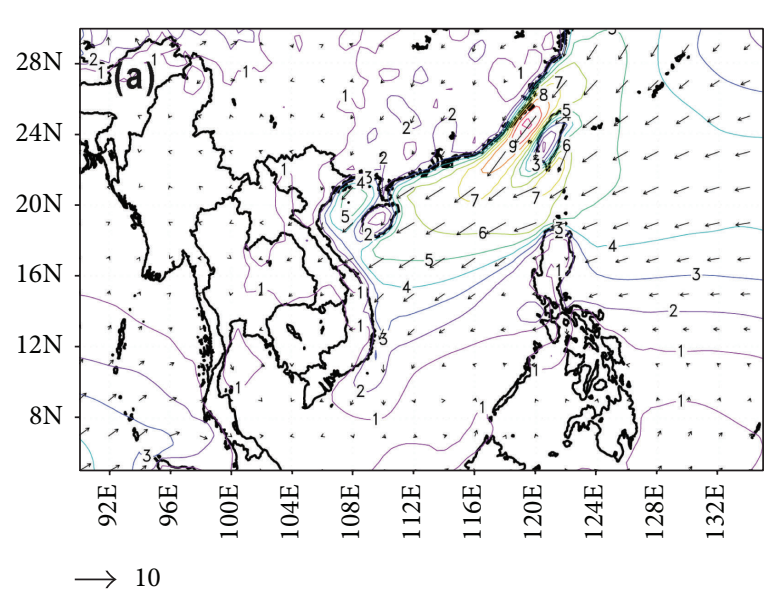

(a)

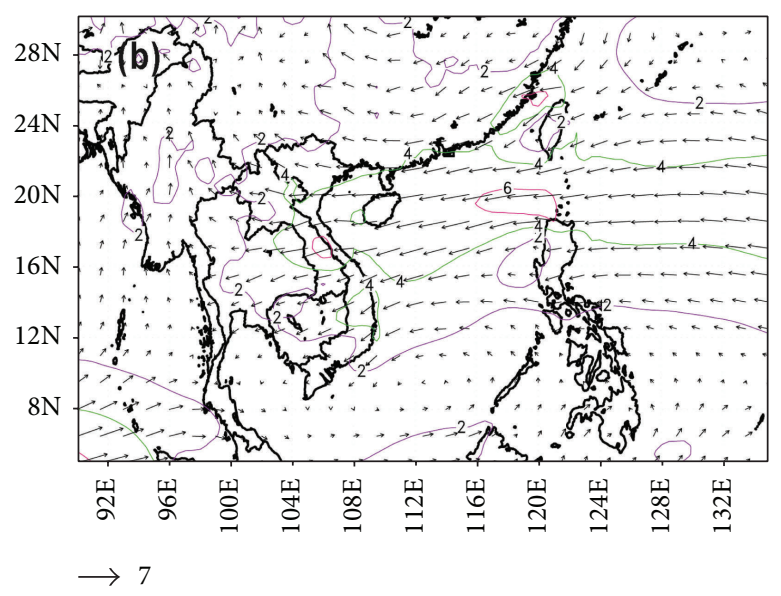

(b)

FIGURE 4: Long-term (1980-2007) means of wind vectors $\left(\mathrm{m} \mathrm{s}^{-1}\right)$ computed from CFSR data for the (a) $10 \mathrm{~m}$ and (b) $850 \mathrm{hPa}$ levels during three autumn months (SON).

experience decreased autumn rainfall under the El Niño conditions. The reduction in rainfall is from $-3.9 \%$ (Dong $\mathrm{Ha}$ station) to $-30.3 \%$ (Nha Trang). More significant reductions in rainfall occur at stations in Central Vietnam including Hue, Da Nang, Tam Ky, Tra My, and Quang Ngai. The reductions in total three-month rainfall at the four stations are about $-17.9 \%(329 \mathrm{~mm})$ or higher (Table 3$)$.

Student's $t$-test has been performed to examine the statistical significance of the differences in mean states of the three different ENSO conditions (El Niño, La Niña, and ENSOneutral) compared with the rainfall climatological means at the 13 stations. To perform the tests, rainfall at the 13 coastal stations for the three autumn months (SON) are first used to compute the regional average rainfall for each of the 28 years in the data set. The data sets from nine El Niño, ten La Niña, and nine ENSO-neutral years are then compared to the 28 -year climatology data set. The $95 \%$ and $90 \%$ confidence levels are selected to examine the statistical significance of the differences of each of the ENSO conditions with the climatology. Results in Table 4 show that the differences in rainfall between the ENSO-neutral condition and the climatology are not significant at either the $95 \%$ or $90 \%$ 
TABLE 4: The probability ( $P$ value) associated with Student's $t$-test for El Niño, La Niña, and ENSO-neutral conditions compared to climatology for rainfall, relative vorticity, and sea level pressure. Columns 4 and 5 indicate the statistical significance at $95 \%$ and $90 \%$ confidence levels, respectively. A YES means that the difference between mean values in an ENSO condition and climatology is statistically significant.

\begin{tabular}{|c|c|c|c|c|}
\hline Variables & Condition & $P$ value & $95 \%$ level & $90 \%$ level \\
\hline \multirow{3}{*}{ Regional average rainfall } & El Niño & 0.007 & YES & YES \\
\hline & La Niña & 0.100 & no & YES \\
\hline & Neutral & 0.146 & no & no \\
\hline \multirow{3}{*}{ Relative vorticity at $10 \mathrm{~m}$ level } & El Niño & 0.013 & YES & YES \\
\hline & La Niña & 0.019 & YES & YES \\
\hline & Neutral & 0.465 & no & no \\
\hline \multirow{3}{*}{ Relative vorticity at $850 \mathrm{hPa}$ level } & El Niño & 0.019 & YES & YES \\
\hline & La Niña & 0.022 & YES & YES \\
\hline & Neutral & 0.491 & no & no \\
\hline \multirow{3}{*}{ Sea level pressure } & El Niño & 0.009 & YES & YES \\
\hline & La Niña & 0.021 & YES & YES \\
\hline & Neutral & 0.346 & no & no \\
\hline
\end{tabular}

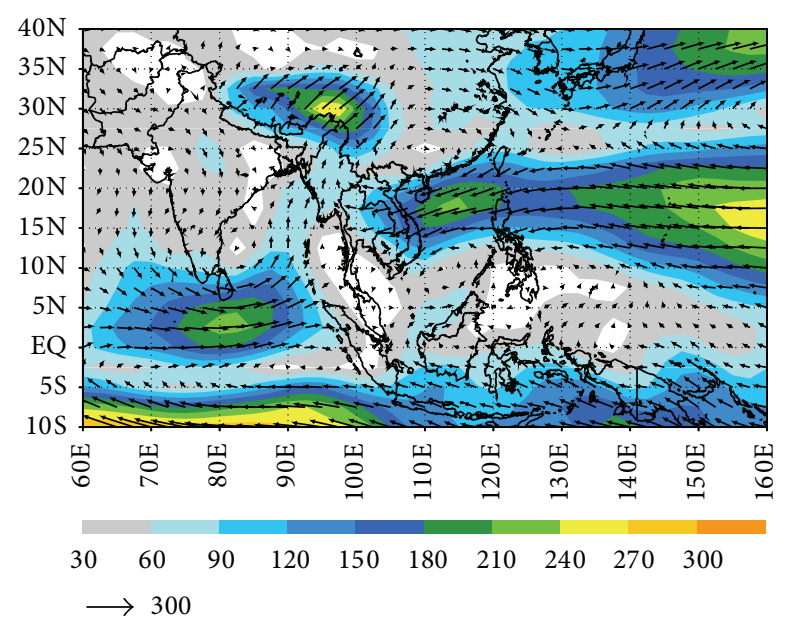

FIGURE 5: Long-term (1980-2007) means of total moisture transport vectors during three autumn months (SON). The magnitude of the moisture transport vectors $\left(\mathrm{kg} \mathrm{m}^{-1} \mathrm{~s}^{-1}\right)$ is shown by shading.

confidence levels. The difference in rainfall between the El Niño condition and the climatology is statistically significant at both the $95 \%$ and $90 \%$ confidence levels. The differences in rainfall between the La Niña condition and the climatology are not statistically significant at the $95 \%$ confidence level but are statistically significant at the $90 \%$ confidence level (Table 4).

The negative rainfall anomalies during El Niño years are largest in October. In October, all 13 coastal stations have anomalies ranging from $-13 \%$ to $-40 \%$ compared to the longterm means (Table 3 ). The station with the largest rainfall reduction in October is $\mathrm{Ba}$ To $(-45.7 \%)$. In September and November, the reductions in rainfall do not occur at all stations. In September, most of the northern stations (except $\mathrm{Ky} \mathrm{Anh}$ ) in the ECV region have negative rainfall anomalies, while the stations located in southern ECV have positive rainfall anomalies. In November, the spatial distribution of rainfall anomalies is opposite to that in September, with the stations in the northern part of the ECV region having positive rainfall anomalies ranging from $9 \%$ to $32 \%$, while the stations in the southern part of the ECV region have negative rainfall anomalies ranging from $-13 \%$ to $-38 \%$ (Table 3 ).

The spatial distribution of rainfall reduction in El Niño can be summarized as follows. First, a deficit of rainfall occurs over the northern stations in September. It then extends to all coastal stations in October, with the largest reductions of $-13 \%$ to $-40 \%$ occurring during this month. In November, the negative anomalous rainfall is only seen at the southern stations (Table 3 ). Rainfall anomalies computed from APHRODITE data (Figure 6) also show a noticeable rainfall reduction of about $-20 \mathrm{~mm}$ to $-80 \mathrm{~mm}$.

Moisture transports and atmospheric circulation patterns under ENSO conditions are known to have significant effects on rainfall distribution over some regions [7, 14-18]. In this work, low-level winds, SLP, and total moisture transport are analyzed to investigate the mechanism for the rainfall reduction in the ECV region. Wind vector anomalies at the $10 \mathrm{~m}$ (Figure 7(a)) and $850 \mathrm{hPa}$ (Figure 7(b)) levels show that, during El Niño, there is an anticyclonic circulation centered in the East Sea. The anticyclonic wind circulation in Figure 7 is consistent with the SLP anomaly field in Figure 8, with an anomalous high pressure over the region. The presence of the anticyclone results in weakening of the North East monsoon over the East Sea as well as weakening of the largescale circulation, which brings abundant moist air from the Western North Pacific (WNP) to the East Sea regions.

Student's $t$-test is again used to investigate the statistical significance of the anomalies in low-level wind circulations and SLP. The means of relative vorticity and SLP within a box covering $8^{\circ}-21^{\circ} \mathrm{N}$ and $108^{\circ}-120^{\circ} \mathrm{E}$ over the East Sea (Figures 7 and 8) are computed for every year in the data set. Three 


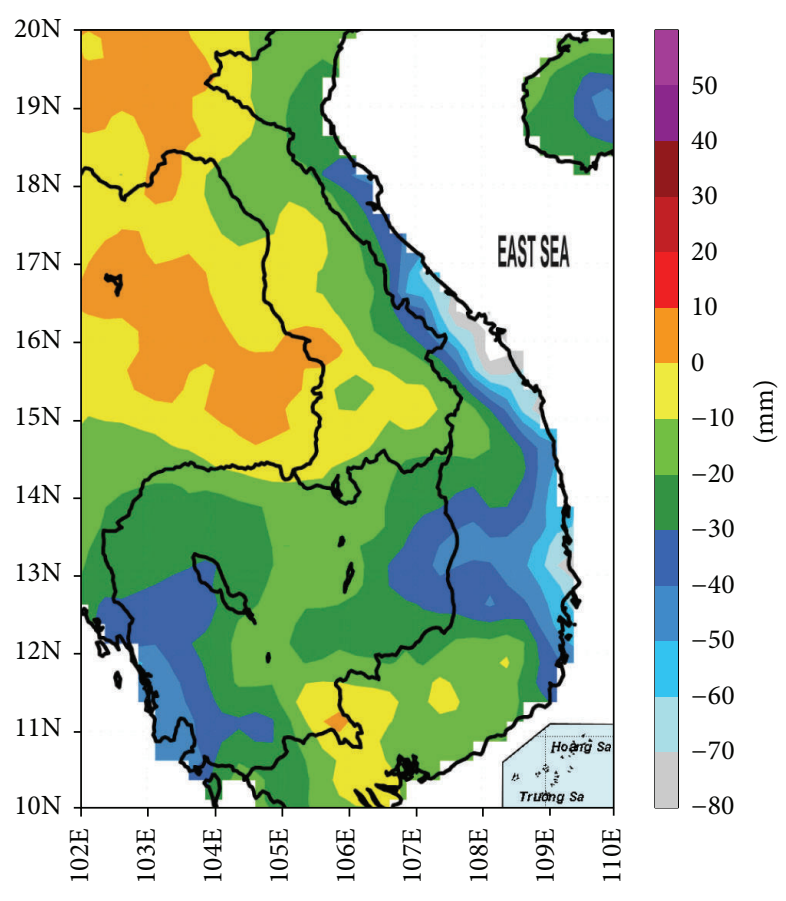

Figure 6: Rainfall anomalies (mm) during El Niño conditions for the three autumn months from APHRODITE data.

subsets, for El Niño, La Niña, and ENSO-neutral conditions, are used to test against the 28-year climatology data set. The results in Table 4 show that the differences in anomalies of $850 \mathrm{hPa}$ relative vorticity, $10 \mathrm{~m}$ relative vorticity, and SLP between the ENSO-neutral condition and the climatology are not statistically significant. For both El Niño and La Niña conditions, the differences in anomalies of low-level wind circulations and SLP are all statistically significant at the 95\% confidence level (Table 4).

The total moisture transport during the autumn season under El Niño conditions (Figure 9(a)) shows a significant reduction in moisture transport over the East Sea (Figure 9(a)) compared to the long-term mean (Figure 5). In particular, the long-term mean over the center of the East Sea (Figure 5) is about $210-240 \mathrm{~kg} \mathrm{~m}^{-1} \mathrm{~s}^{-1}$ compared to $180-210 \mathrm{~kg} \mathrm{~m}^{-1} \mathrm{~s}^{-1}$ during El Niño (Figure 9(a)). The anomalous moisture transport regime (Figure 9(b)) over ECV shows a significant easterly moisture transport. There is a $-10 \%\left(\sim 20 \mathrm{~kg} \mathrm{~m}^{-1} \mathrm{~s}^{-1}\right)$ to $-35 \%\left(\sim 40 \mathrm{~kg} \mathrm{~m}^{-1} \mathrm{~s}^{-1}\right)$ reduction in moisture transport into the region (Figure 9). There are reductions in the two moisture channels, which may have negative effects on rainfall amounts over the ECV region in El Niño conditions. One is located in the WNP located to the north of the East Sea region, and the other is located over the low latitudes, reducing moisture transport from the low latitudes and the Southern Hemisphere to the East Sea (Figure 9(b)).

In summary, the reduction in rainfall over ECV in the El Niño condition relates to the formation of an anomalous anticyclone associated with the high SLP anomaly over
TABLE 5: Same as Table 3 but for La Niña conditions.

\begin{tabular}{lcccc}
\hline Stations & Autumn & Sep. & Oct. & Nov. \\
\hline Ha Tinh & -3.6 & -16.8 & 8.9 & -14.7 \\
Ky Anh & 4.6 & -22.4 & 23.6 & 0.8 \\
Dong Hoi & 5.2 & -5.6 & 16.8 & -5.4 \\
Dong Ha & 0.3 & -10.4 & 10.1 & -5.4 \\
Hue & 19.5 & -19.7 & 16.1 & 45.2 \\
Da Nang & 16.7 & -8.8 & 18.4 & 30.6 \\
Tam Ky & 17.8 & -17.8 & 11.0 & 43.3 \\
Tra My & 11.4 & -11.9 & -1.0 & 32.6 \\
Quang Ngai & 16.4 & -14.4 & 10.3 & 38.1 \\
Ba To & 9.5 & -17.9 & -2.9 & 30.2 \\
Quy Nhon & 8.7 & -17.6 & 4.1 & 27.9 \\
Tuy Hoa & 9.9 & -5.2 & -8.1 & 39.7 \\
Nha Trang & 14.8 & -13.2 & 14.9 & 28.3 \\
\hline
\end{tabular}

the East Sea region. The anomalous anticyclone is related to a weakening of the North East monsoon over the East Sea and associated weakening of the moisture transport into the East Sea and the ECV regions.

3.2.2. Effects of La Niña. Similar to the El Niño condition discussed above, the mean rainfall at 13 coastal stations for the autumn months during the La Niña years (Table 2) is compared with the 28-year mean rainfall. Results from Table 5 show that most (12 out of 13) of the coastal stations experience increased rainfall in La Niña conditions, except Ha Tinh station, which is located on the northern tip of ECV. Here, the decrease in rainfall is about $-4 \%$. The largest rainfall increase $(19.5 \%)$ is at Hue station (Table 5). The increased rainfall in the ECV region during Niña conditions can be seen from APHRODITE data (Figure 10). The figure shows that the entire region south of $17^{\circ} \mathrm{N}$, including South Vietnam, experiences increased rainfall in autumn during La Niña years. In contrast, the region north of $18^{\circ} \mathrm{N}$, including North Vietnam, shows a decrease in rainfall (Figure 10).

Although the total autumn rainfall increases at most stations, the September mean rainfall for all stations decreases by $-5 \%$ to $-22 \%$. In October, an increase in rainfall occurs at the northern stations, while some southern stations (Tra $\mathrm{My}, \mathrm{Ba} \mathrm{To}$, Tuy Hoa) still experience a decrease in rainfall. In November, ten out of 13 coastal stations have increased rainfall (20\% to $40 \%)$. All stations located south of ECV also have rainfall increases, whereas stations located north of ECV experience rainfall decreases (Table 5). This study indicates that rainfall in ECV is influenced by the local terrain of the Truong Son Range and is not always increased under La Niña conditions.

Overall, autumn rainfall is increased during the La Niña conditions. The positive anomalous rainfall starts at the northern stations in October and then moves to the 


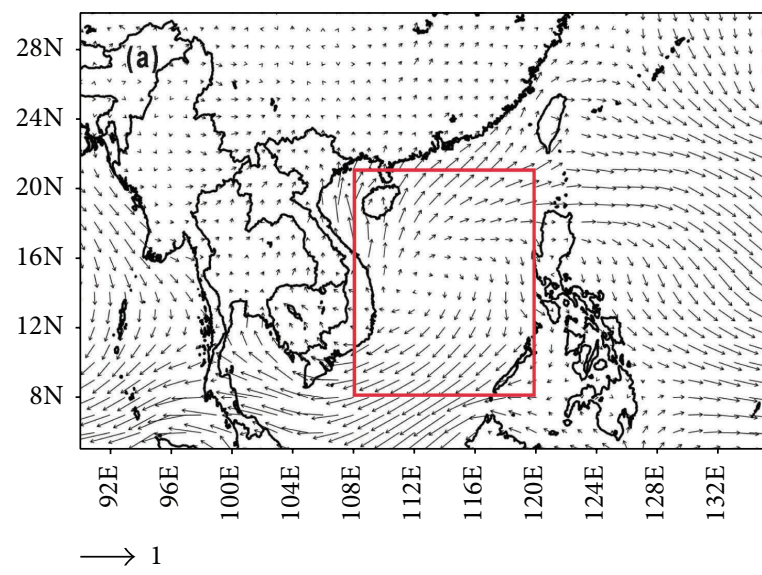

(a)

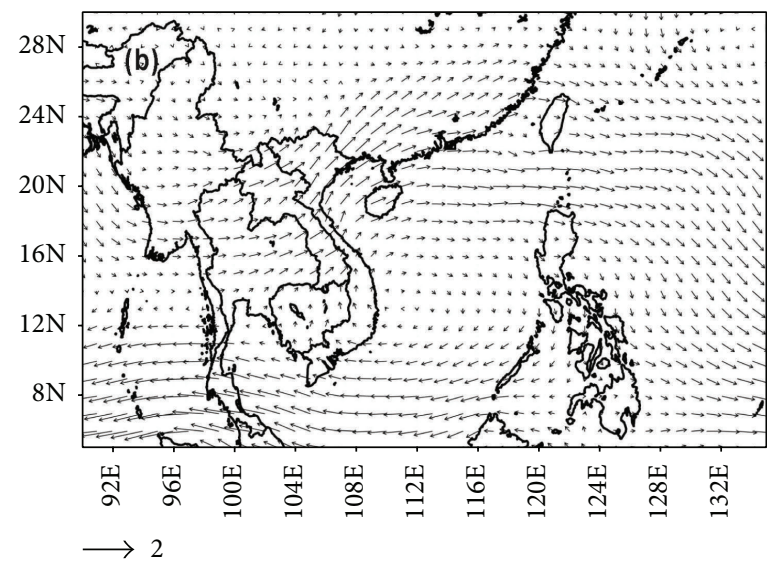

(b)

Figure 7: Wind vector anomalies $\left(\mathrm{m} \mathrm{s}^{-1}\right)$ for the El Niño autumn months for the (a) $10 \mathrm{~m}$ level and (b) $850 \mathrm{hPa}$ level. The red box $\left(8^{\circ}-21^{\circ} \mathrm{N}\right.$, $108^{\circ}-120^{\circ} \mathrm{E}$ ) is the area used to compute vorticity and SLP anomaly indices.

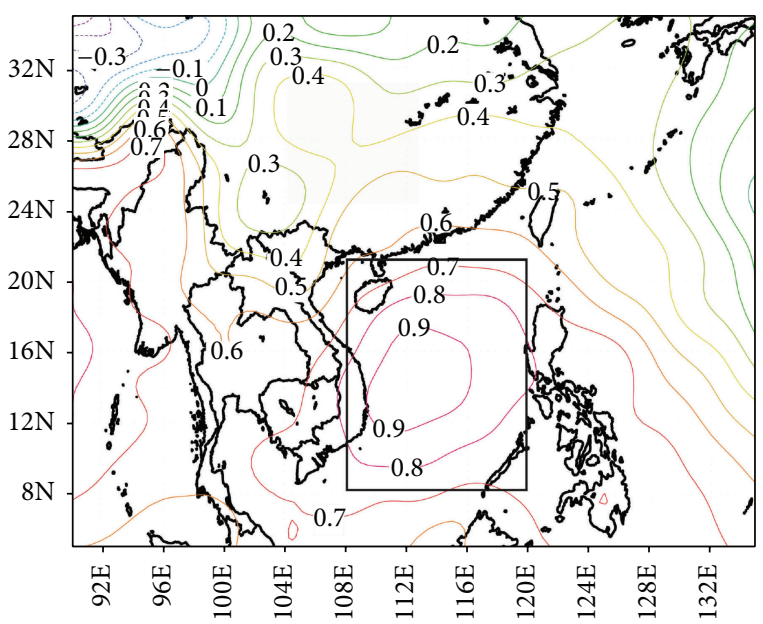

Figure 8: Anomalies of sea level pressure (hPa) during El Niño autumn months.

southern stations in November. However, a decrease in rainfall is observed at all stations in September, at some southern stations in October and at some northern stations in November.

The increase in autumn rainfall in ECV during La Niña conditions may be associated with anomalous circulations (Figure 11). A near-surface $(10 \mathrm{~m})$ anomalous cyclonic circulation (Figure 11(a)) extends to the $850 \mathrm{hPa}$ level (Figure 11(b)). This wind regime is associated with anomalous low SLP located over the East Sea (Figure 12). The anomalous winds are associated with enhancement of the North East monsoon during La Niña conditions.

The distribution of total moisture transport in Figure 13 shows that total atmospheric moisture over the East Sea region mainly comes from the western and central Pacific. There is another moisture source from the north of Malaysia which enhances the moisture availability in the East Sea region (Figure 13(a)). The latter is absent during El Niño conditions (Figure 9(a)). The total moisture increases over the East Sea region by about $10 \%$ to $20 \%\left(15-25 \mathrm{~kg} \mathrm{~m}^{-1} \mathrm{~s}^{-1}\right)$. It is important to note that the enhanced moisture channels over the East Sea region during La Niña conditions are extended inland, covering the ECV region (Figure 13(b)), where the positive rainfall anomalies are observed (Figure 10). It can be inferred that the increase in rainfall over the ECV region is associated with the enhancement of the North East monsoon and the moisture transport.

To investigate the physical mechanisms involved in the formation of the anomalous anticyclone during El Niño and cyclone during La Niña years, the means of SSTA within the box over the East Sea (Figure 8) for all El Niño years and La Niña years were computed. The mean for El Niño years was positive, while that for La Niña years was negative. The results agree with Wu et al. [19] (their Figures 3(a) and 3(b)). The positive (negative) SSTA in El Niño (La Niña) years may imply that the anomalous anticyclone (cyclone) in El Niño (La Niña) years may not be thermally driven by the local SSTA in the East Sea region. The formation of the anomalous anticyclone/cyclone in the East Sea may be dynamically driven by large-scale circulations.

For La Niña conditions, the stronger winter monsoon over the northern part of the East Sea (Figure 14(a)) is associated with a negative large-scale SSTA (Wu at al. [19], their Figure 3) and a large-scale anomalous high pressure (Wu at al. [19], their Figure 1). The stronger-than-normal Northeast winter monsoon over the northern part of the East Sea results in the formation of the northern part of the anomalous cyclone in the East Sea (Figure 11). The southern part of the anomalous cyclone in the East Sea may be associated with strengthening of the cross-equator flow over the northeast portion of the Indian Ocean. During La Niña conditions, the cross-equator flows from $80^{\circ} \mathrm{E}$ to $100^{\circ} \mathrm{E}$ (Figure $14(\mathrm{a})$ ) are stronger than during El Niño conditions (Figure 14(b)) and in the climatology (Figure 14(c)). 


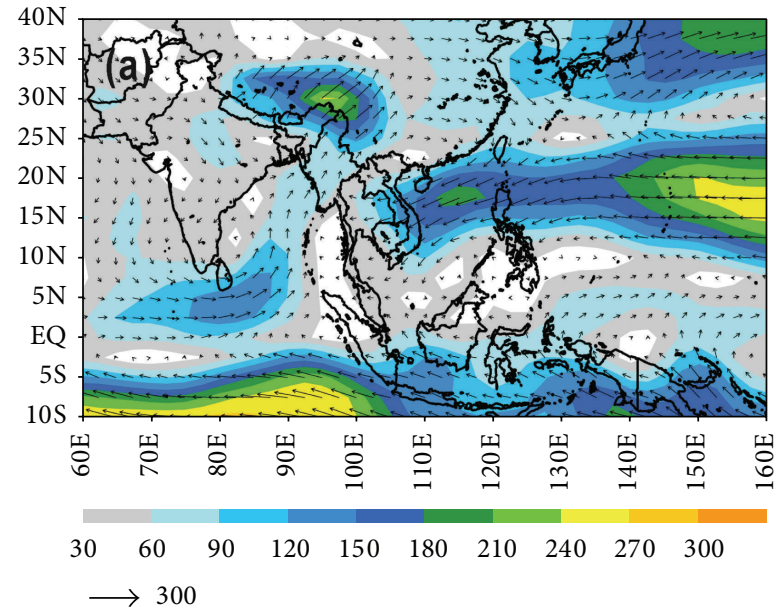

(a)

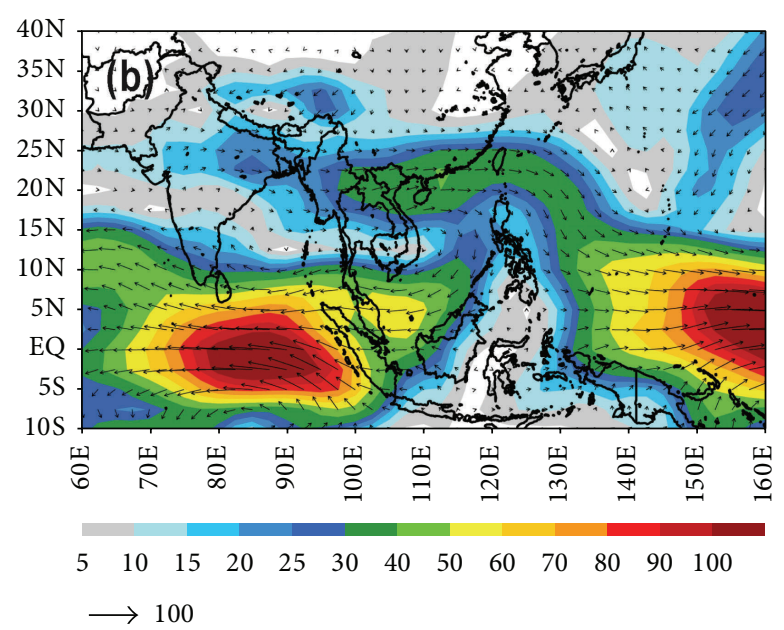

(b)

FIGURE 9: (a) Mean and (b) anomalies of total moisture transport vectors $\left(\mathrm{kg} \mathrm{m}^{-1} \mathrm{~s}^{-1}\right)$ for El Niño autumn months. The magnitude of moisture transport vectors $\left(\mathrm{kg} \mathrm{m}^{-1} \mathrm{~s}^{-1}\right)$ is shown by shading.

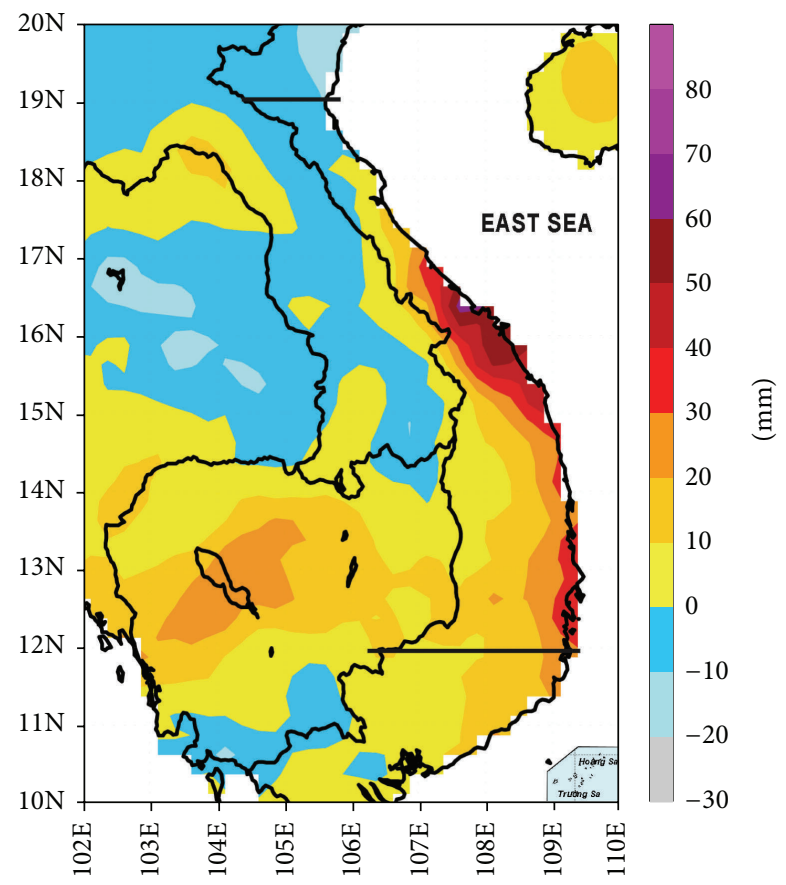

FIGURE 10: Rainfall anomalies (mm) during La Niña conditions for the three autumn months from APHRODITE data.

The stronger southwest flow in the region from 0 to $10^{\circ} \mathrm{N}$ in the Indian Ocean enhances southwest flow in the southern East Sea (Figure 14(a)) during La Niña conditions to form the southern portion of the anomalous cyclone in the East Sea (Figure 11). For El Niño conditions, the formation of the anomalous anticyclone in the East Sea (Figure 7) may follow the same mechanism as during La Niña conditions but with the opposite effects of weakening both the northeast winter monsoon over the northern portion of the East Sea and the southwest flows in the region from $0^{\circ}-10^{\circ} \mathrm{N}$ in the Indian Ocean.

In this paper, we also found that there is an asymmetry in the impacts of El Niño and La Niña, as mentioned by study of Wu et al. [19]. The negative rainfall anomalies during El Niño years in the ECV region are apparently larger than the positive anomalies during La Niña years. The mean of station rainfall anomalies in El Niño (La Niña) years is -335 (134) mm. The magnitude of rainfall anomalies in El Niño years is about 34\% larger than in La Niña years. The asymmetry in rainfall is in agreement with the asymmetry in wind and SLP pressure anomalies. The magnitudes of the mean anomalies in the box covering $8^{\circ}-21^{\circ} \mathrm{N}$ and $108^{\circ}-120^{\circ} \mathrm{E}$ (Figures $7(\mathrm{a}$ ) and 8) of SLP and vorticities at the $10 \mathrm{~m}$ and $850 \mathrm{hPa}$ levels were computed to further investigate the asymmetry. The magnitudes of anomalies in El Niño years are $37.8 \%, 34 \%$, and $58 \%$ larger than those in La Niña years for SLP and vorticities at $10 \mathrm{~m}$ and $850 \mathrm{hPa}$ levels, respectively. The asymmetry has been shown to be related to SSTA. Wu at al. [19] suggested that the amplitudes of cold SSTA during El Niño years are significantly greater than those of warm SSTA during La Niña years. The larger SSTA during El Niño years may result in more significant effects during El Niño conditions than during La Niña conditions.

In summary, under the influence of La Niña, the increase in total autumn rainfall in the ECV region compared to the long-term mean is related to (1) the stronger North East monsoon with the cyclonic wind anomalies over the East Sea; (2) the increase of the two moisture sources, that is, the one from the Central and Western Pacific and the other from the low latitudes north of Malaysia.

To investigate the effect of ENSO conditions on the temporal variation of rainfall distribution over the ECV region, the average monthly rainfall is computed for the 13 coastal stations for El Niño and La Niña years between 1980 


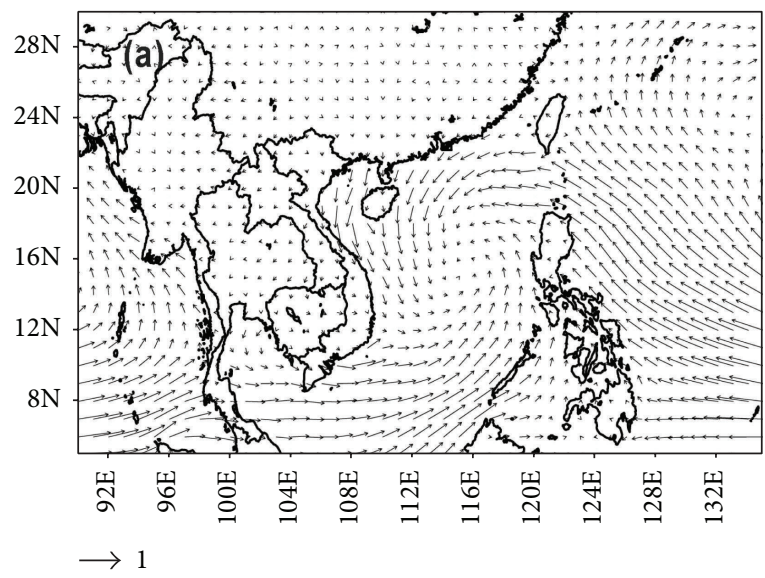

(a)

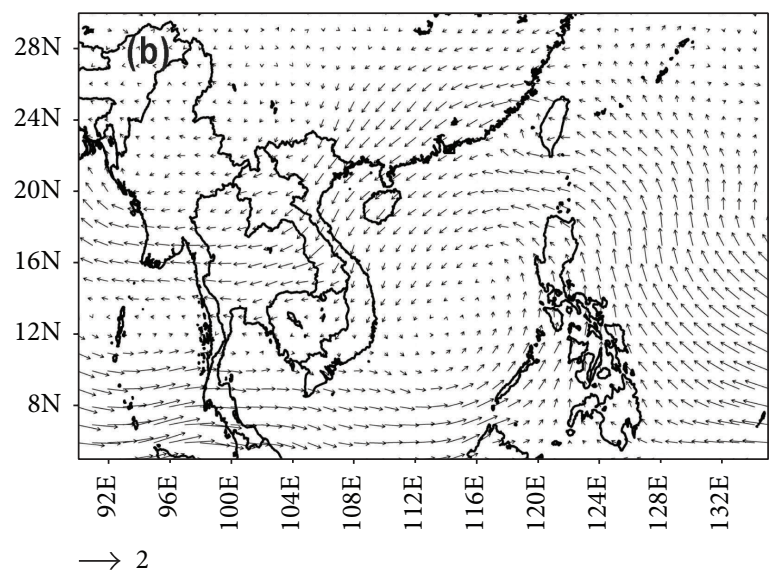

(b)

FIGURE 11: Vectors of wind anomalies $\left(\mathrm{m} \mathrm{s}^{-1}\right)$ during the La Niña autumn months for the (a) $10 \mathrm{~m}$ and (b) $850 \mathrm{hPa}$ levels.

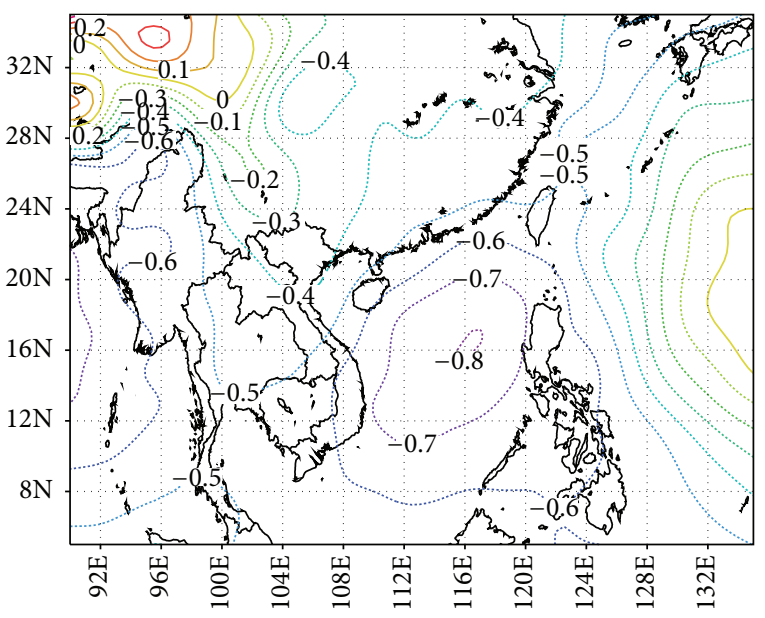

FIGURE 12: Anomalies of sea level pressure (hPa) during La Niña autumn months.

and 2007 (Figure 15). It can be seen from Figure 15 that, in September, the El Niño phase causes an increase in rainfall, whereas the La Niña phase causes a decrease in rainfall over the ECV region. In October and November there are significant decreases in rainfall during the El Niño phase and increases during the La Niña phase occur. Overall, in the La Niña years, the total autumn rainfall in ECV increases and the rainfall distribution is more concentrated in the later months (Oct., Nov.) (Figure 15), which suggests that the rainy season shifts toward later months during the La Niña years. Figure 15 also shows that a significant decrease in April and May rainfall over ECV occurs during the El Niño years.

\section{Summary and Discussion}

In this study, 28 years (1980-2007) of data were used to investigate the effects of ENSO on the autumn (SON) rainfall over the ECV region. The data include rainfall at stations, gridded APHRODITE rainfall, and reanalysis data from NCEP.

The results show that, during El Niño condition, autumn rainfall in Central Vietnam is reduced by about $-10 \%$ to $-30 \%$ at most stations. In contrast, during La Niña conditions, the total autumn rainfall is increased by about $9 \%$ to $19 \%$ at most stations. These results are in agreement with previous studies. In this study, we found that, in addition to increase in rainfall, the La Niña conditions also clearly affect the temporal distribution of the monthly rainfall over the ECV region. The rainy season shifts toward October and November and less rain occurs in September during the La Niña years.

The decrease in the autumn rainfall over Central Vietnam during El Niño years seems to be linked to the weakening of the North East monsoon circulation and the weakening of the cross-equatorial flows over the Indian Ocean. During El Niño years, there is an anticyclonic circulation, which is associated with the positive anomalous SLP over the East Sea. In contrast, during La Niña years, the North East monsoon strengthens and a cyclonic wind anomaly is formed over the East Sea. As a result, there is an increase in the moisture supply to the region of about $10 \%$ to $20 \%$ and therefore an increase in rainfall over ECV. The locations of the local rainfall maxima are almost consistent with the locations of the local maximum terrain heights. This indicates that the interaction between the North East monsoon winds and the elevated terrain may be one of the important factors in regulating the rainfall regime in the ECV region. This is illustrated by Figure 16. The important factors controlling the rainfall regime include the Truong Son Mountain range, the North East monsoon, and the moisture sources. The most significant differences between El Niño and La Niña conditions are that (1) the North East monsoon is weaker during El Niño conditions compared to La Niña conditions; (2) the secondary moisture source over the southern region of the East Sea is absent during El Niño conditions (Figure 16(a)); and (3) during El Niño, there is an anticyclonic wind anomaly over the East Sea (Figure 16(a)), while there is a cyclonic wind anomaly there during La Niña (Figure 16(b)). 


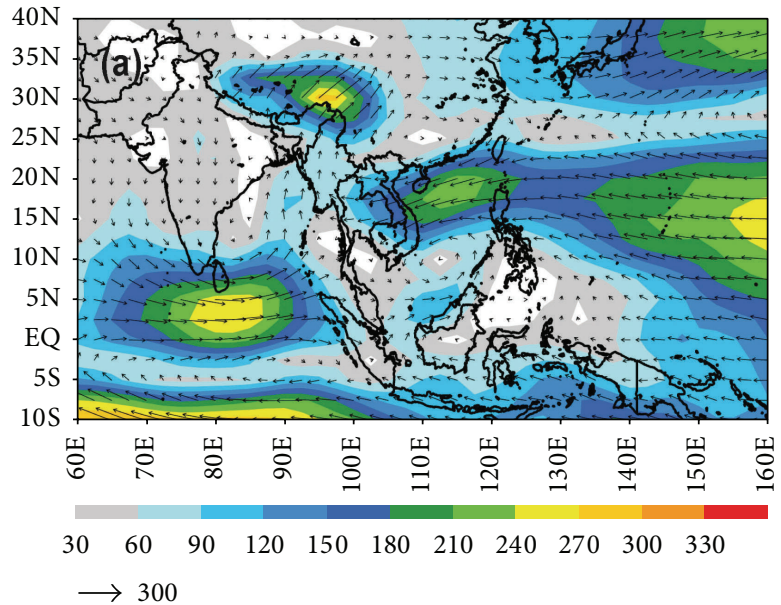

(a)

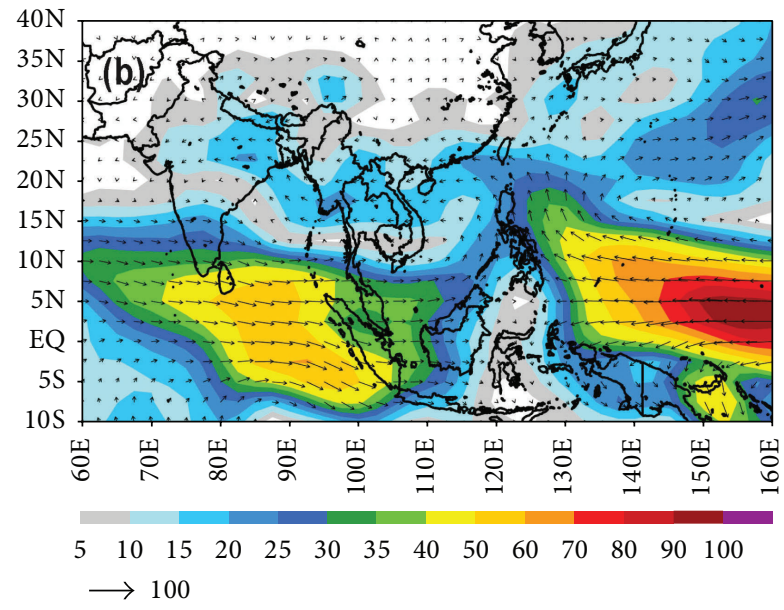

(b)

Figure 13: (a) Mean and (b) anomalies of total moisture transport vectors $\left(\mathrm{kg} \mathrm{m}^{-1} \mathrm{~s}^{-1}\right)$ for La Niña autumn months. The magnitude of moisture transport vectors $\left(\mathrm{kg} \mathrm{m}^{-1} \mathrm{~s}^{-1}\right)$ is shown by shading.

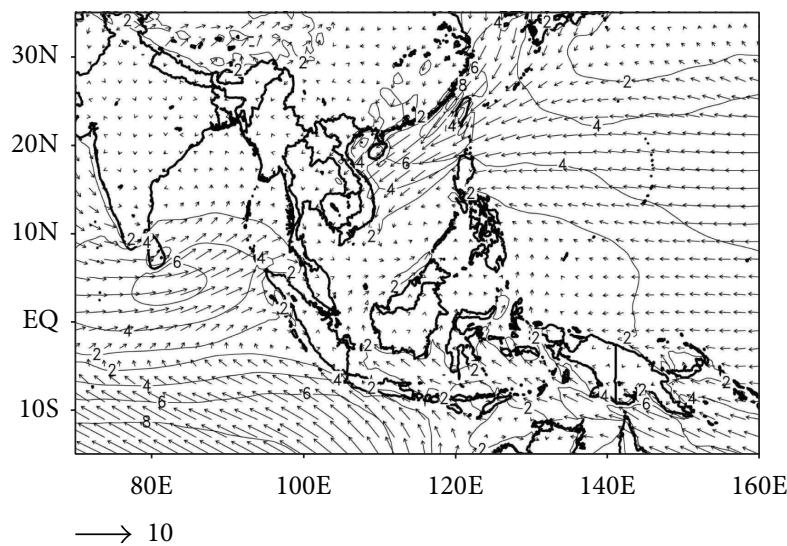

(a)

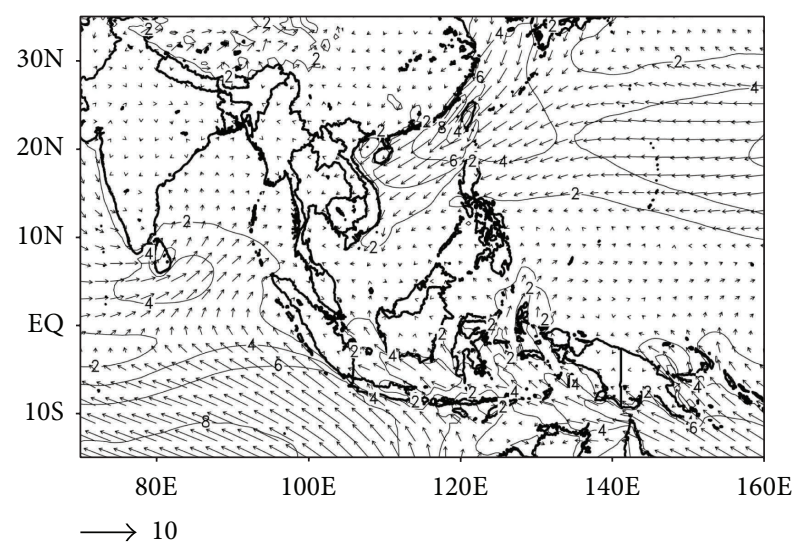

(b)

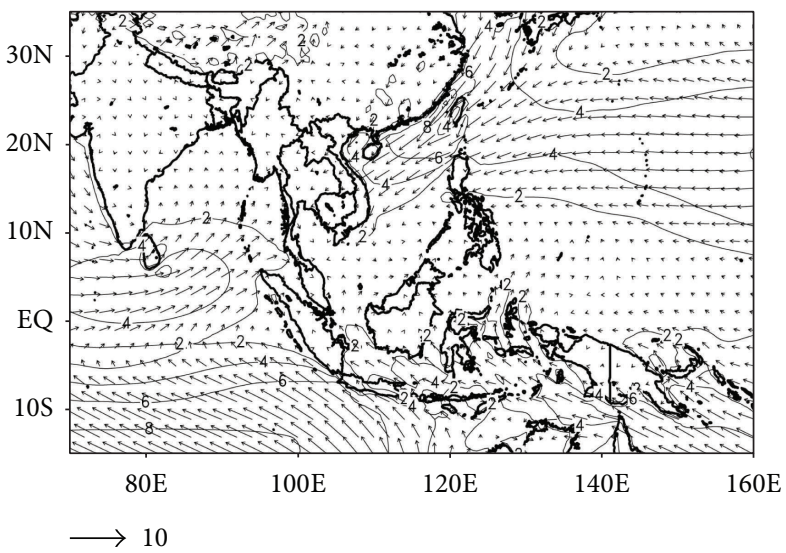

(c)

Figure 14: Means of the three autumn months (SON) of wind vectors and speed (contours, $\mathrm{m} \mathrm{s}^{-1}$ ) at $10 \mathrm{~m}$ levels for (a) La Niña, (b) El Niño, and (c) climatology (1980-2007) conditions. 


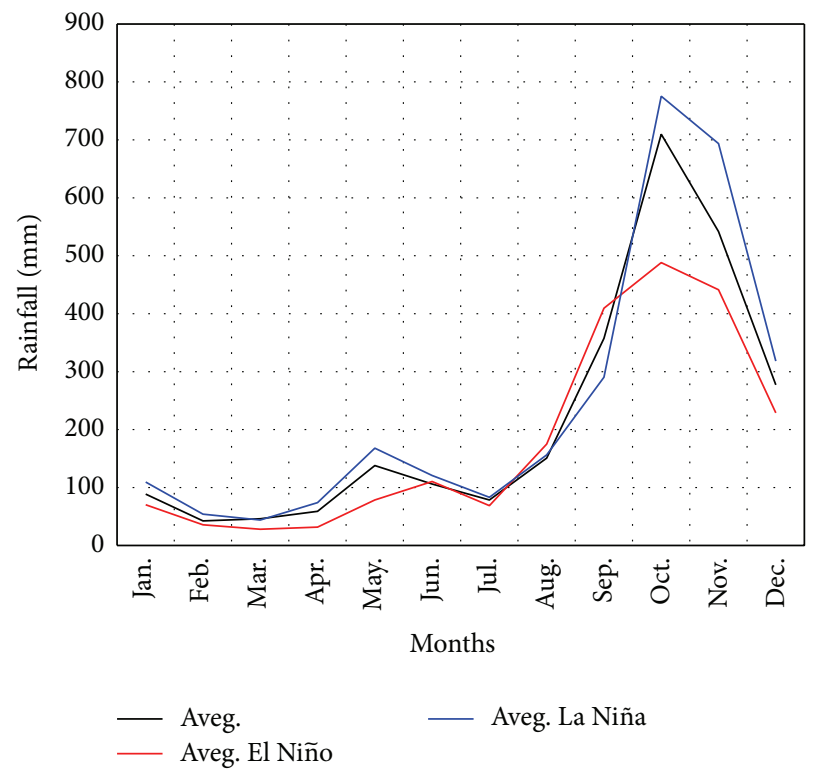

FIGURE 15: Annual variation of monthly rainfall (mm) averaged from all 13 coastal stations in the ECV region for 1980-2007: mean (black), El Niño years (red), and La Niña years (blue).

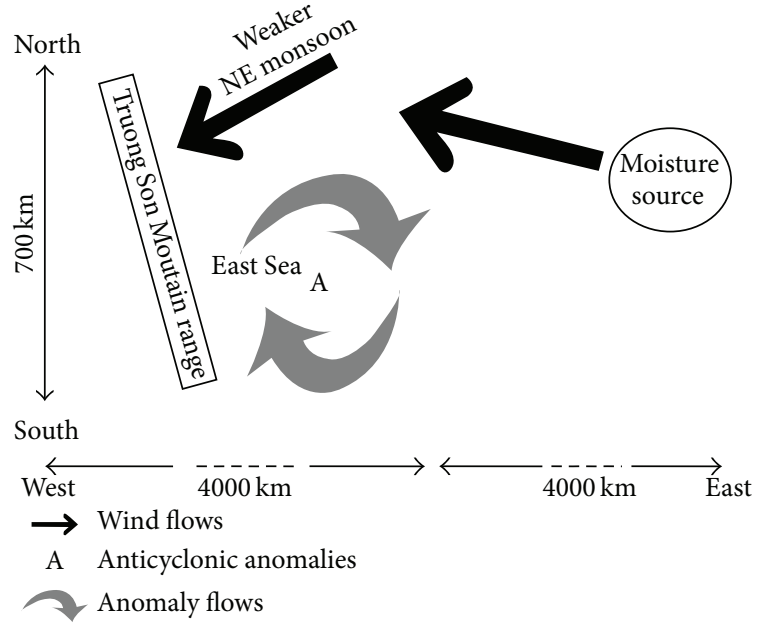

(a)

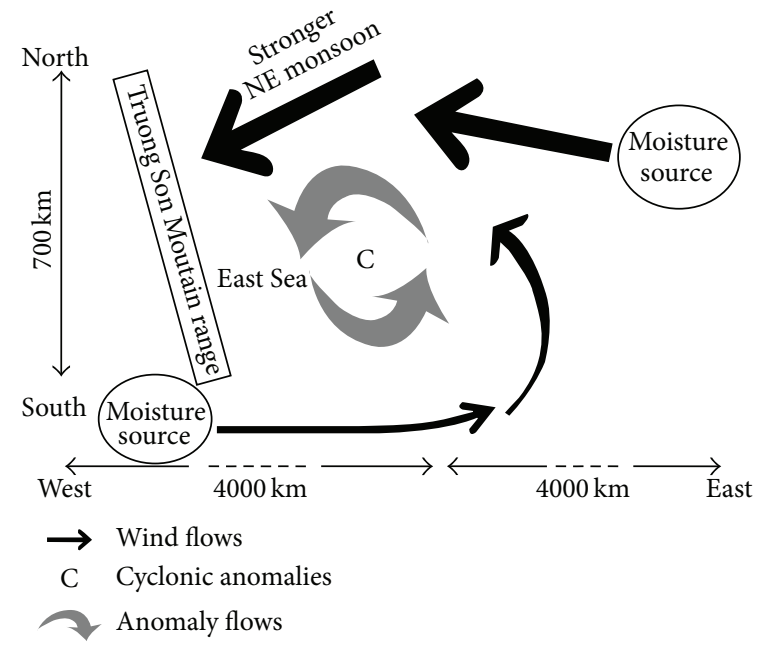

(b)

FIGURE 16: Schematic diagrams of atmospheric circulations for (a) El Niño and (b) La Niña conditions. Wind flows are indicated by thick, dark arrows. Wind anomalies are indicated by gray arrows.

\section{Conflict of Interests}

The authors declare that there is no conflict of interests regarding the publication of this paper.

\section{Acknowledgments}

This work was supported by the Vietnam Ministry of Science and Technology Foundation under the Project no. DT.NCCB-DHUD.2011-G/12. The authors would like to thank the two reviewers for their comments and suggestions; Mr. Nguyen Thanh Tung for help with plotting
Figure 1; Dr. Kim Nguyen, Dr. Jack Katzfey at CSIRO, Australia, Mr. David Eugene Hitzl at UHM, Hawaii, USA, and Mr. Tran Dinh Trong for discussions and help with proofreading.

\section{References}

[1] D. N. Nguyen and T. H. Nguyen, Vietnam Climate and Climate Resources, Agriculture Publisher, Hanoi, Vietnam, 2004.

[2] T.-C. Chen, J.-D. Tsay, M.-C. Yen, and J. Matsumoto, "Interannual variation of the late fall rainfall in central Vietnam," Journal of Climate, vol. 25, no. 1, pp. 392-413, 2012. 
[3] S. Yokoi and J. Matsumoto, "Collaborative effects of cold surge and tropical depression-type disturbance on heavy rainfall in Central Vietnam," Monthly Weather Review, vol. 136, no. 9, pp. 3275-3287, 2008.

[4] D. N. Nguyen, Things to Know about El Niño and La Niña, Scientific and Technical Publisher, Hanoi, Vietnam, 2000.

[5] D. N. Nguyen, "ENSO impact on weather, climate, environment and social-economic development in Vietnam," National Project Report on Scientific Research, Hanoi, Vietnam, 2002.

[6] M.-C. Yen, T.-C. Chen, H.-L. Hu et al., "Interannual variation of the fall rainfall in central Vietnam," Journal of the Meteorological Society of Japan, vol. 89, pp. 259-270, 2011.

[7] R. Zhang and A. Sumi, "Moisture circulation over East Asia during El Niño episode in northern winter, spring and autumn," Journal of the Meteorological Society of Japan, vol. 80, no. 2, pp. 213-227, 2002.

[8] T. T. Mai and L. T. T. Hoang, "The relationship between rainfall over Vietnam and ENSO indices," Journal of Hydrometeorology, vol. 553, pp. 13-23, 2007.

[9] D. N. Nguyen, "ENSO impact on drought in Central and Tay Nguyen region Vietnam," Journal of Hydrometeorology, vol. 530, pp. 1-15, 2005.

[10] D. N. Nguyen, "Effect of ENSO extremes in temperature and rainfall in Vietnam," in Proceedings of the 10th Scientific IMHEN Conference Report, vol. 1, pp. 236-242, 2007.

[11] V. Nguyen, "Effect of ENSO to disasters in Thua Thien Hue," Journal of Hydrometeorology, vol. 572, pp. 22-30, 2008.

[12] V. Sminov and G. Moor, "Short-term and seasonal variability of the atmospheric water vapour transport through the Mackenzie River Basin," Journal of Hydrometeorology, vol. 2, pp. 441-452, 2001.

[13] V. E. Kousky and R. W. Higgins, "An alert classification system for monitoring and assessing the ENSO cycle," Weather and Forecasting, vol. 22, no. 2, pp. 353-371, 2007.

[14] J. Liu, R. E. Stewart, and K. K. Szeto, "Moisture transport and other hydrometeorological features associated with the severe 2000/01 drought over the western and central Canadian Prairies," Journal of Climate, vol. 17, no. 2, pp. 305-319, 2004.

[15] I. Simmonds, D. Bi, and P. Hope, "Atmospheric water vapor flux and its association with rainfall over China in summer," Journal of Climate, vol. 12, no. 5, pp. 1353-1367, 1999.

[16] V. K. Valsala and M. Ikeda, "An Extreme drought event in the, 2002, summer monsoon rainfall and its mechanism proved with a moisture flux analysis," SOLA, vol. 1, pp. 173-176, 2005.

[17] X. Zhou, Y. Ding, and P. Wang, "Moisture transport in the Asian summer monsoon region and its relationship with summer precipitation in China," Acta Meteorologica Sinica, vol. 24, no. 1, pp. 31-42, 2010.

[18] T. J. Zhou and R. C. Yu, "Atmospheric water vapor transport associated with typical anomalous summer rainfall patterns in China," Journal of Geophysical Research: Atmospheres, vol. 110, no. D8, 2005.

[19] B. Wu, T. Li, and T. Zhou, "Asymmetry of atmospheric circulation anomalies over the western north Pacific between El Niño and La Niña," Journal of Climate, vol. 23, no. 18, pp. 4807-4822, 2010. 

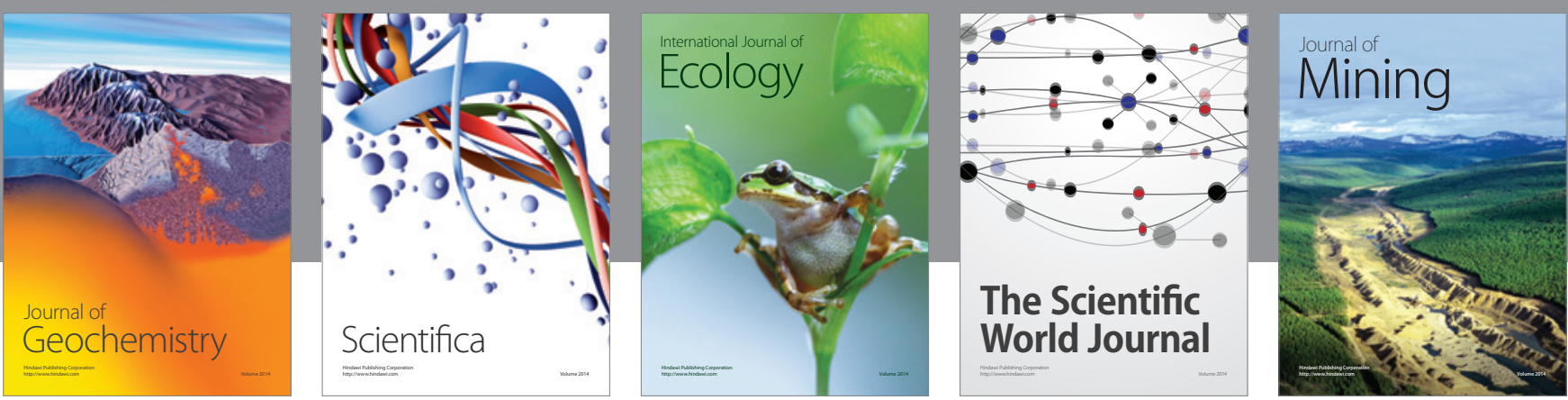

The Scientific World Journal
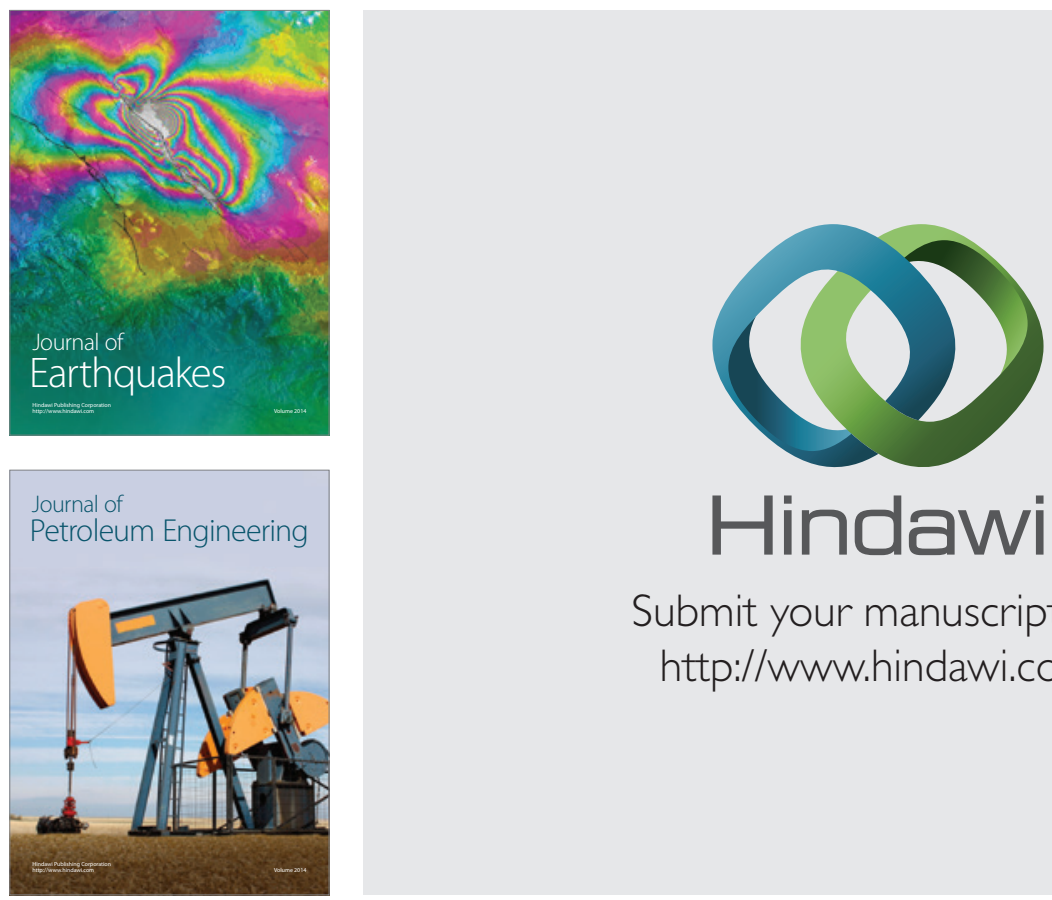

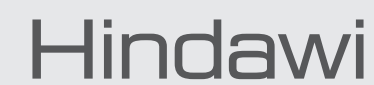

Submit your manuscripts at

http://www.hindawi.com
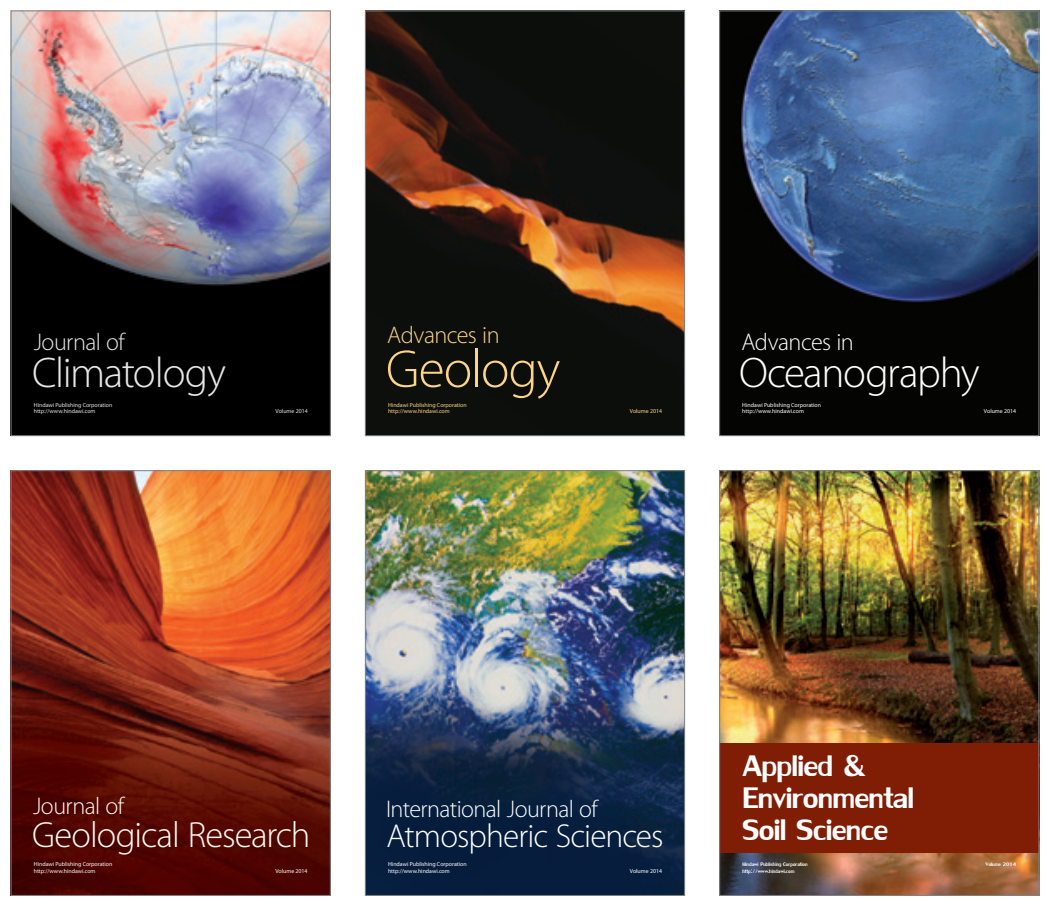
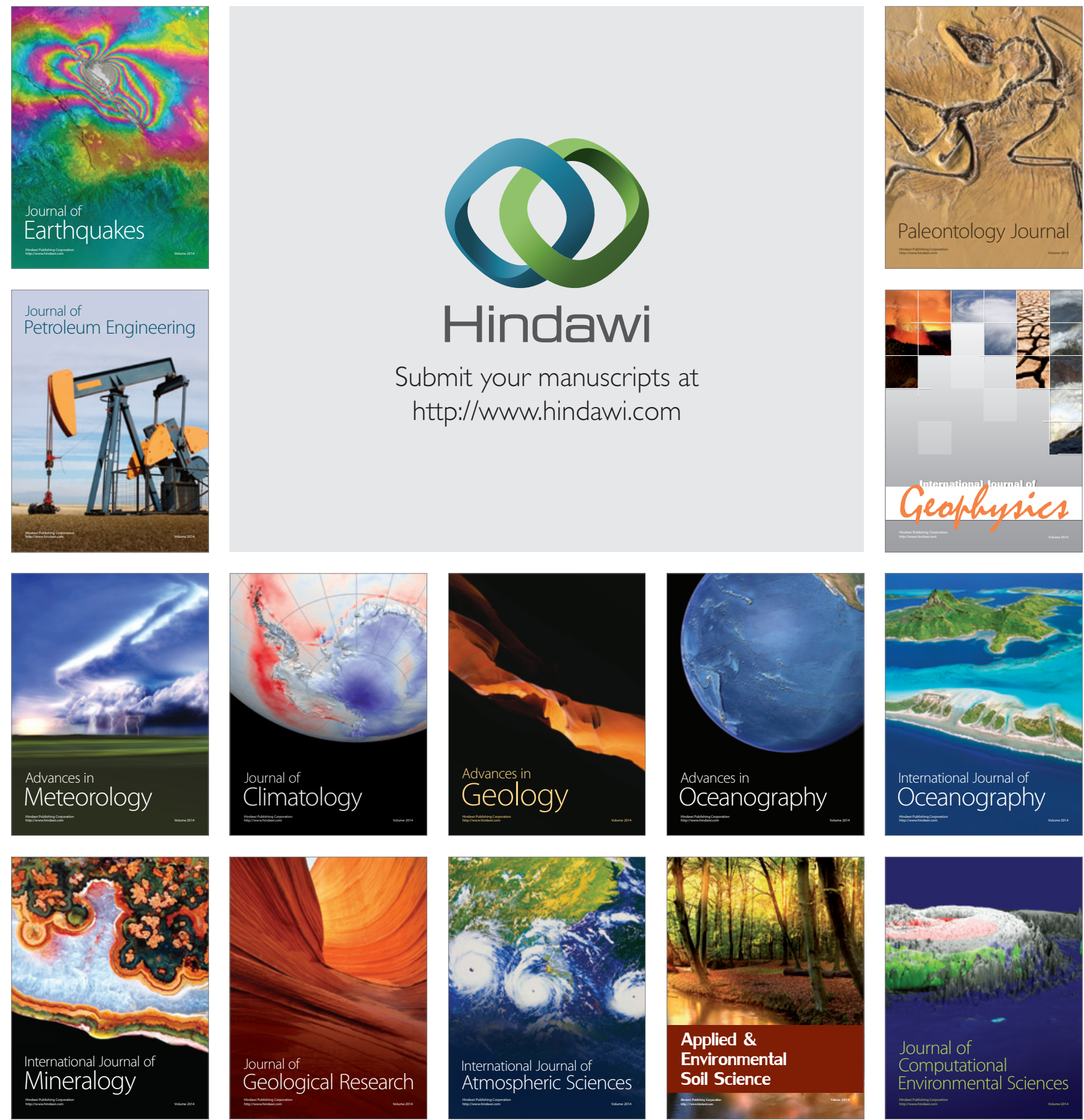